\title{
Redevelopment Model For Residential Building: A Case Study
}

\author{
Nikita P. Kushare ${ }^{1}$, R. V. Devalkar ${ }^{2}$ \\ ${ }^{1}$ (P.G. Student, Department of Civil Engineering) \\ ${ }_{2}^{2}$ (Assistant Professor, Department of Civil Engineering) \\ Email: npk94@rediffmail.com ${ }^{1}$,devalkar.rajanikant@kbtcoe.org ${ }^{2}$
}

\begin{abstract}
Because of inadequacy and high rate of land within superior areas, today many persons who are staying within old residential structures are going for redevelopment. The old buildings whose life is above 25 years can decide on redevelopment if they are uneconomical. Demolishing the old urban structures and construct a new one accompanied by a few extra provisions free of cost to old owners of residential flats by nominating the right developer is redevelopment. The intension of this paper is to identify and analyze parameters or factors for choosing the housing project of redevelopment. The questionnaire survey is carried out amongst owners of residential flats using Likert 5 point scale and the data required for analysis was collected. Then the factors are analyzed using SPSS software. The result shows that selection of the right developer, legal aspects, provision of an extra area, provision of amenities are the top factors for selection of housing project of redevelopment.
\end{abstract}

Index Terms-Redevelopment; SPSS; Critical factors.

\section{INTRODUCTION}

The population is increasing day by day in urban areas. Therefore the demand for land in superior areas is also increasing. Many persons in cities have suffered due to heavy housing prices[1]. Redevelopment of old apartment houses has become relatively popular in recent years. Redevelopment process faces plenty of problems from the beginning[2]. Those who propose to conduct a redevelopment of residential buildings face a problem due to the dilapidated building. The difficulty is whether to perform a redevelopment or not[3], due to restricted knowledge about their existing structure in terms of construction[4]. The main issue while going for redevelopment is the high demand for a good developer[5]. If old buildings are shabby, then they require some amount of repairs. Instead of moving ahead with repairing work, redevelopment can be a great option as repairing work only expands the life of building to some years[6]. There are many potential benefits of redevelopment. Developer makes a gain from it by selling extra flats and residents also get profit such as an extra area, amenities, good environment, increase in flat's value and rent payment[7]. Residents have to find alternate accommodation while the old building is redeveloped or up-to possession of new flats[8]. Redevelopment is done on the basis of carpet area[9]. The factors are finalized through an extensive literature survey and discussion with experts from the construction industry. The responses were collected from owners of the apartment houses[10]. The factors involved in the decision-making process of redevelopment are identified and analyzed using SPSS software[11]. The factors which are identified and analyzed reflects the redevelopment project success[12]. Therefore redevelopment is an intgrable process which upgrades land property rights and land use efficiency[13].

\section{OBJECTIVES}

- To identify parameters or factors for selection of housing project of redevelopment.

- To analyze parameters or factors using SPSS software for housing project of redevelopment.

\section{METHODOLOGY}

The data collection is carried out with reviewing literature, discussion with experts and apartment flat owners. For that the questionnaire is prepared. The questionnaire was carried through face to face interviews with apartment flat owners. We have interviewed 35 respondents for data analysis. The factors are analyzed using SPSS software. We adopt descriptive statistics method for data analysis. The factor evaluation was done according to their mean.

\section{DATA COLLECTION}

Data was collected using journal papers, discussion with experts and apartment flat owners related to redevelopment. Total 18 factors were identified. Table 1 shows the identified factors.

Table 1. Identification of factors related to housing project of redevelopment.

\begin{tabular}{|l|l|}
\hline $\begin{array}{c}\text { Sr. } \\
\text { No. }\end{array}$ & \multicolumn{1}{|c|}{ Factors } \\
\hline 1 & Terms and conditions with the society \\
\hline 2 & $\begin{array}{l}\text { Consent for going ahead with the demolition of } \\
\text { their existing building and constructing a new } \\
\text { building }\end{array}$ \\
\hline 3 & $\begin{array}{l}\text { Consent for moving out of the property and } \\
\text { shifting to an alternate accommodation }\end{array}$ \\
\hline 4 & Rent compensation \\
\hline 5 & Profitability \\
\hline 6 & Area or place for alternate accommodation \\
\hline 7 & Selection of right developer \\
\hline
\end{tabular}


International Journal of Research in Advent Technology, Vol.7, No.4, April 2019

E-ISSN: 2321-9637

Available online at www.ijrat.org

\begin{tabular}{|l|l|}
\hline 8 & Financial stability of developer \\
\hline 9 & Track record of developer \\
\hline 10 & Quality check \\
\hline 11 & Legal aspects \\
\hline 12 & Life cycle of building \\
\hline 13 & Time of redevelopment or possession \\
\hline 14 & Bank guarantee \\
\hline 15 & Transfer of development rights \\
\hline 16 & $\begin{array}{l}\text { Redevelopment on the basis of carpet or built } \\
\text { up area }\end{array}$ \\
\hline 17 & Provision of extra area \\
\hline 18 & Provision of amenities \\
\hline
\end{tabular}

\begin{tabular}{|l|l|l|l|l}
\hline 18 & Provision of amenities & 35 & 4.8000 & 3 \\
\hline
\end{tabular}

\section{RESULT AND DISCUSSION}

Using descriptive statistics and SPSS software the factor analysis is carried out. The respondent's data is entered into SPSS software and the mean is calculated. As per mean of each factor, the ranking of factor is obtained and the top ten factors having greater mean are considered as critical factors for the implementation of a housing project of redevelopment. The factors should be considered before going for redevelopment.

Table 3. Rank of Factors.

\section{DATA ANALYSIS}

The respondents were asked to rate each factor based on Likert 5 point scale, where 1 is not important, 2 is slightly important, 3 is moderately important, 4 is important and 5 is very important. Then the factors are analyzed using SPSS software for 35 respondents and mean, rank for all factors were found out. Table 2 shows the descriptive statistics for all factors.

Table 2. Descriptive statistics for factors.

\begin{tabular}{|c|c|c|c|c|}
\hline $\begin{array}{l}\text { Sr. } \\
\text { No. }\end{array}$ & Factors & $\mathbf{N}$ & Mean & Rank \\
\hline 1 & $\begin{array}{l}\text { Terms and conditions } \\
\text { with the society }\end{array}$ & 35 & 4.7143 & 4 \\
\hline 2 & $\begin{array}{l}\text { Consent for going } \\
\text { ahead with the } \\
\text { demolition of their } \\
\text { existing building and } \\
\text { constructing a new } \\
\text { building }\end{array}$ & 35 & 4.3429 & 7 \\
\hline 3 & $\begin{array}{l}\text { Consent for moving out } \\
\text { of the property and } \\
\text { shifting to an alternate } \\
\text { accommodation }\end{array}$ & 35 & 4.2286 & 9 \\
\hline 4 & Rent compensation & 35 & 4.0000 & 11 \\
\hline 5 & Profitability & 35 & 4.0000 & 11 \\
\hline 6 & $\begin{array}{l}\text { Area or place for } \\
\text { alternate } \\
\text { accommodation }\end{array}$ & 35 & 3.8000 & 12 \\
\hline 7 & $\begin{array}{lll}\begin{array}{l}\text { Selection } \\
\text { developer }\end{array} & \text { of right } \\
\end{array}$ & 35 & 4.8571 & 1 \\
\hline 8 & $\begin{array}{l}\text { Financial stability of } \\
\text { developer }\end{array}$ & 35 & 4.4000 & 6 \\
\hline 9 & $\begin{array}{l}\text { Track record of } \\
\text { developer }\end{array}$ & 35 & 4.0857 & 10 \\
\hline 10 & Quality check & 35 & 4.2286 & 9 \\
\hline 11 & Legal aspects & 35 & 4.8286 & 2 \\
\hline 12 & Life cycle of building & 35 & 4.2857 & 8 \\
\hline 13 & $\begin{array}{l}\text { Time of redevelopment } \\
\text { or possession }\end{array}$ & 35 & 4.3429 & 7 \\
\hline 14 & Bank guarantee & 35 & 4.3429 & 7 \\
\hline 15 & $\begin{array}{ll}\begin{array}{l}\text { Transfer } \\
\text { development rights }\end{array} & \text { of } \\
\end{array}$ & 35 & 4.2286 & 9 \\
\hline 16 & $\begin{array}{l}\text { Redevelopment on the } \\
\text { basis of carpet or built } \\
\text { up area }\end{array}$ & 35 & 4.4286 & 5 \\
\hline 17 & Provision of extra area & 35 & 4.8000 & 3 \\
\hline
\end{tabular}

\begin{tabular}{|l|l|l|l|}
\hline $\begin{array}{c}\text { Sr. } \\
\text { No. }\end{array}$ & \multicolumn{1}{|c|}{ Factors } & \multicolumn{1}{|c|}{ Mean } & Rank \\
\hline 1 & Selection of right developer & 4.8571 & 1 \\
\hline 2 & Legal aspects & 4.8286 & 2 \\
\hline 3 & Provision of extra area & 4.8000 & 3 \\
\hline 4 & Provision of amenities & 4.8000 & \\
\hline 5 & $\begin{array}{l}\text { Terms and conditions with } \\
\text { the society }\end{array}$ & 4.7143 & 4 \\
\hline 6 & $\begin{array}{l}\text { Redevelopment on the basis } \\
\text { of carpet or built up area }\end{array}$ & 4.4286 & 5 \\
\hline 7 & $\begin{array}{l}\text { Financial stability of } \\
\text { developer }\end{array}$ & 4.4000 & 6 \\
\hline 8 & $\begin{array}{l}\text { Consent for going ahead } \\
\text { with the demolition of their } \\
\text { existing building and } \\
\text { constructing a new building }\end{array}$ & 4.3429 & \multirow{2}{*}{7} \\
\hline 9 & Bank guarantee & 4.3429 & \multirow{2}{|l|}{} \\
\hline 10 & Time of redevelopment & 4.3429 & \multirow{2}{|l|}{} \\
\hline
\end{tabular}

\section{CONCLUSION}

Redevelopment is a cost effective and efficient way for old housing project. It was found that the analyzed critical factors are very important while going for redevelopment. Selection of right developer and legal aspects are the most important factors from the owner's perspective. Going for redevelopment is a very big decision by appointing right developer.

\section{REFERENCES}

[1] S. Mu. "Community Building in Social-mix Public Housing: Participatory Planning of Redevelopment Plan". Procedia Social and Behavioural Sciences, pages 755-762, 2016.

[2] J. Antucheviciene, M. Pavlovskis, D. Migilinskas, V. Zigmund and I. Urba. "Problems in reconstruction projects, BIM uses and decisionmaking: Lithuanian case studies". Procedia Engineering, pages 125-128, 2017.

[3] F. Isidori. "A structural project: Redevelopment of the historic center of Wuhu". Frontiers of Architectural Research, pages 100-118, 2015.

[4] E. Radziszewska-Zielina, G. Sladowski and M. Sibielak. "Planning the reconstruction of a historical building by using a fuzzy stochastic network". Automation in Construction, pages 242-257, 2017. 
[5] A. Ade Bilau, E. Witt, C. Malalgoda, I. Lill and D. Amaratunga. "Integrated measures for managing permanent housing reconstruction". Procedia Engineering, pages 403-410, 2018.

[6] V. Pukhkal, V. Murgul and M. Garifullin. "Reconstruction of buildings with a superstructure mansard: Options to reduce energy intensity of buildings". Procedia Engineering, pages 624627,2015 .

[7] G. Ragheb, H. El-Shimy and A. Ragheb. "Land for Poor: Towads Sustainable Master Plan for Sensitive Redevelopment of Slums". Procedia Social and Behavioural Sciences, pages 417-427, 2016.

[8] I. Levin, K. Arthurson and A Ziersch. "Experiences of Tenants Relocation in the Carlton Public Housing Estate Redevelopment, Melbourne". Urban Policy and Research, volume 36, pages 354-366.

[9] S. Morimoto, T. Serizawa and S. Honda. "Large depot redevelopment project in central Tokyo". Transportation Research Procedia, pages 331-343, 2017.

[10]E. Yetiskul, S. Kayasu and S. Y. Ozdemier. "Local responses to urban redevelopment projects: The case of Beyoglu, Istanbul". Habitat International, pages 159-167, 2016.

[11]H. Ronagh, M. Mortazavi, P. Sharafi, M. Rashidi and B. Samali. "Identification of Factors and Decision Analysis of the Level of Modularization in Building Construction". Journal of Architectural Engineering, volume 24.

[12] T. Zhou, Y. Zhou and G. Liu. "Comparison of critical success paths for historic district renovation and redevelopment projects in China". Habitat International, pages 54-58, 2017.

[13] Y. Lai, J. Wang and W. Lok. "Redefining property rights over collective land in the urban redevelopment of Shenzhen, China". Land Use Policy, pages 48-493, 2017. 